\title{
Thrombin generation
}

Citation for published version (APA):

Hemker, H. C., Al Dieri, R., De Smedt, E., \& Beguin, S. (2006). Thrombin generation: A function test of the haemostatic-thrombotic system. Thrombosis and Haemostasis, 96(5), 553-561.

https://doi.org/10.1160/TH06-07-0408

Document status and date:

Published: 01/01/2006

DOI:

10.1160/TH06-07-0408

Document Version:

Publisher's PDF, also known as Version of record

\section{Please check the document version of this publication:}

- A submitted manuscript is the version of the article upon submission and before peer-review. There can be important differences between the submitted version and the official published version of record.

People interested in the research are advised to contact the author for the final version of the publication, or visit the DOI to the publisher's website.

- The final author version and the galley proof are versions of the publication after peer review.

- The final published version features the final layout of the paper including the volume, issue and page numbers.

Link to publication

\footnotetext{
General rights rights.

- You may freely distribute the URL identifying the publication in the public portal. please follow below link for the End User Agreement:

www.umlib.nl/taverne-license

Take down policy

If you believe that this document breaches copyright please contact us at:

repository@maastrichtuniversity.nl

providing details and we will investigate your claim.
}

Copyright and moral rights for the publications made accessible in the public portal are retained by the authors and/or other copyright owners and it is a condition of accessing publications that users recognise and abide by the legal requirements associated with these

- Users may download and print one copy of any publication from the public portal for the purpose of private study or research.

- You may not further distribute the material or use it for any profit-making activity or commercial gain

If the publication is distributed under the terms of Article $25 \mathrm{fa}$ of the Dutch Copyright Act, indicated by the "Taverne" license above, 


\title{
Thrombin generation, a function test of the haemostatic- thrombotic system
}

\author{
H. Coenraad Hemker, Raed Al Dieri, Erik De Smedt, Suzette Béguin \\ Synapse BV, Cardiovascular Research Institute Maastricht, University of Maastricht, Maastricht, The Netherlands
}

\begin{abstract}
Summary
By the use of a fluorogenic thrombin substrate and continuous calibration of each individual sample, it is now possible to obtain a thrombin generation (TG) curve (or thrombogram) in plasma, with or without platelets, in an easy routine procedure at high throughput and with an acceptable experimental error $(<5 \%)$. Evidence is growing that the parameters of the thrombogram, and notably the area under the curve (endogenous thrombin potential, ETP), are useful in assessing bleeding- or thrombotic risk and its modification by antithrombotic- or haemostatic treatment. Available data strongly suggest that conditions (congenital, acquired, drug-induced) that increase TG all cause a
\end{abstract}

\section{Keywords}

Thrombin generation, hypercoagulability, antithrombotics, haemophilia

\section{Introduction}

As we know since Virchow, the occurrence and extent of thrombosis is determined by the force of the local trigger, the local flow conditions and the readiness of the blood to clot. For a long time this "coagulability" has been silently identified with clotting times, as the name already indicates. However, more than $95 \%$ of all thrombin forms after clotting has taken place (1), and one may well pose the question why (2). Anyhow, it is there and is likely to serve a function. It is therefore potentially interesting to assess this independent variable and investigate its clinical usefulness. Independent variable, indeed, because the time that it takes for clotting to start may or may not relate to the bulk amount of thrombin formed. For example, tissue factor (TF)- induced clotting times correlate with the amount of thrombin formed during anti-vitamin $\mathrm{K}$ treatment but do not in heparin treatment, where a modified clotting time (the activated partial thromboplastin time: aPTT) has to be used. Other antithrom- thrombotic tendency and that conditions that decrease TG prevent thrombosis but, beyond a limit, cause bleeding. Diminution of TG is a common denominator of all antithrombotic treatment, including anti-platelet drugs. The thrombogram can also be used as a tool in the search for new antithrombotics and reflects the haemorrhagic or thrombotic side effects of other drugs (e.g. oral contraceptives). The thrombogram thus is a promising new approach to clinical management of bleeding and thrombotic disease as well as a tool in drug research and epidemiology. Our experience at this moment is insufficient, however, to already clearly define its limits.

\section{Thromb Haemost 2006; 96: 553-6I}

botics (e.g. dermatan sulphate) do not prolong any clotting time but they do decrease the amount of thrombin formed. Clotting times and the amount of thrombin formed thus are different things and both merit to be estimated. The reason that this has not been done on a large scale was presumably for purely practical reasons- doing a thrombin generation experiment with the methods available in the early 1980s was close to slave labour. Nevertheless, there were laboratories, such as that of Barrowcliffe in London $(3,4)$ or Josso in Paris $(5,6)$, where this approach was never entirely abandoned. Preserving the heritage of Josso - notably his efforts to bring biochemical research to a direct clinical use - we took up TG measurement in the late 1980s. Noting the interesting type of information that could be obtained, on the one hand we applied it to problems such as the mode of action of heparins and the mechanism of platelet procoagulant action, and on the other hand- and to make it simpler - we automated it further and further. Over the last few years this has resulted in a method that allows the thrombogram to be determined 
at high throughput in the clinical laboratory (7) with a quite acceptable experimental error $(<5 \%)$. In so far as the present evidence goes, it certainly seems to be a welcome extension of the possibilities of the coagulation laboratory.

It does, indeed, produce information that the clotting time will not give. Excessive thrombin formation, for example, always causes a thrombotic tendency but hardly affects any clotting time. It also yields information that can not be obtained from single factor determinations, because the extraordinary complexity of the thrombin generating mechanism makes means that there is no simple relation between factor concentrations and overall function. It is well known, for example, that although haemophilia is a single-factor-disease, the level of the missing factor is not a reliable indicator of the actual bleeding tendency (8). This is probably because the state of the remainder of the clotting system - including the platelets (9) - determines whether or not a given haemophiliac can make sufficient use of the small residual amount of the missing factor.

\section{The place of thrombin in H\&T physiology, or textbook wisdom challenged}

How can thrombin be that important? Until yesterday - and until today in most textbooks - the reigning paradigm of haemostasis states that firstly platelets plug the wound and in a second stage thrombin is formed, which cements together this platelet plug; the bleeding time reflects the first phase and the clotting time the second. This view is based on the classical observation that haemophiliacs have a normal bleeding time and a prolonged clotting time, whereas thrombopenia (-pathy) results in a normal clotting time but a prolonged bleeding time. There are - and have always been - observations that challenge this "textbook view". Prolonged bleeding times have, for example, been observed when TG is profoundly affected, as in severe overdosage of oral anticoagulants (10) or heparin (11). Recently it has been found that mice with defective platelet thrombin receptors show a prolonged bleeding time [see further (12)]. The fact that thrombin is formed before a wound stops bleeding is also in agreement with the old observation that products of thrombin action, such as activated factors V and VIII, appear within seconds in the blood flowing from a wound and diminish when heparin is administrated (13). The activity of thrombin in such blood must be dependent upon platelet function because it is inhibited by aspirin intake (14-17). Recently, early thrombin formation was most convincingly demonstrated in the excellent experiments by the Furie group [as reviewed in (18)]. They visualised exposed tissue factor, aggregated platelets and fibrin at the site of a micro-trauma in a small vessel in the mouse and saw fibrin appear as early as $10-15$ seconds (sec) after the lesion. An optimum concentration of tissue factor, as in the Quick time, clots plasma in 12 $\mathrm{sec}$, hence in these experiments thrombin must have appeared almost simultaneously with the platelet aggregate!

It thus appears that from the very beginning, platelets and plasma achieve haemostasis in close cooperation. In fact, many experiments that support the classical separation between platelet function and the clotting system were conducted under conditions where one of the two was absent or inhibited, such as pla- telets in anticoagulated blood (-plasma) or platelet-free plasma. As soon as platelets and plasmatic coagulation factors are allowed to cooperate, they invariably show early and strong mutual interaction. Thrombin is the most potent platelet activator [see e.g. (12)] and the platelet membrane provides procoagulant phospholipids (19) that allow explosive TG (20). This platelet-clotting interaction, in which circulating tissue factor plays a key role (21), is probably the most important positive feedback mechanism in haemostasis and is responsible for the sudden arrest of blood flow from a wound.

This is not incompatible with the normal bleeding time in haemophiliacs. Early TG is probably triggered by relatively high concentrations of tissue factor $(21,22)$ and thus may be formed in a factor VIII and IX independent manner. The late bleeding seen in haemophilia may well be related to the enhanced fibrinolysis that ensues from insufficient activation of thrombin activated fibrinolysis inhibitor (TAFI) (see below).

Not only haemostasis but also thrombus growth requires thrombin generation. Thrombus growth is due to a series of ligand- and receptor interactions that have been studied in detail [(23) and references therein]. As soon as experiments are carried out under conditions where thrombin can form, tissue factor and thrombin appear to play an important role, especially at low (venous) and intermediate (large artery) shear rates (12, 21, 24-27). At high shear rates an effect of thrombin inhibition is not seen on initial thrombus formation but becomes obvious when the experiment is prolonged (25). One of the functions of the aggregate must be to serve as a niche in which a sufficient concentration of thrombin can build up and diffuse into the surroundings. Where the concentration of thrombin is high enough, new platelets will be recruited and will be activated so that more thrombin will form [see also (28-31)]. Undoubtedly, several mechanisms of aggregation and plug- or thrombus- growth exist in parallel. The relative importance of thrombin- and collagen-dependent mechanisms has been shown to be influenced by the type of injury to a vessel wall (22). As we will see below, clinical observations suggest that the thrombin dependent mechanism must not be neglected.

\section{Normal TG in platelet poor plasma}

To assess the function of the thrombin generating system in a patient, one should be able to measure the concentration of thrombin as a function of time and space in a platelet aggregate at the site of a lesion. At the moment this is technically impossible. A close approximation that is possible is measurement of TG in PRP in the presence of elements of the vessel wall, i.e. tissue factor (TF) and thrombomodulin (TM). Useful partial information can be obtained from observations in platelet poor plasma (PPP).

The general form of any thrombogram is independent of the measuring system and the experimental conditions. It starts with a lag phase, in which only minute amounts of thrombin are formed, after which the full production starts with a sudden burst of thrombin in nanomolar concentrations (Fig. 1). As has been known for a long time, clotting occurs at the start of the explosive burst, i.e. at the end of the lag time (1). The clotting time therefore is a good estimate of the duration of the lag phase and vice versa. During the lag phase, also called the initiation phase (32), hardly 


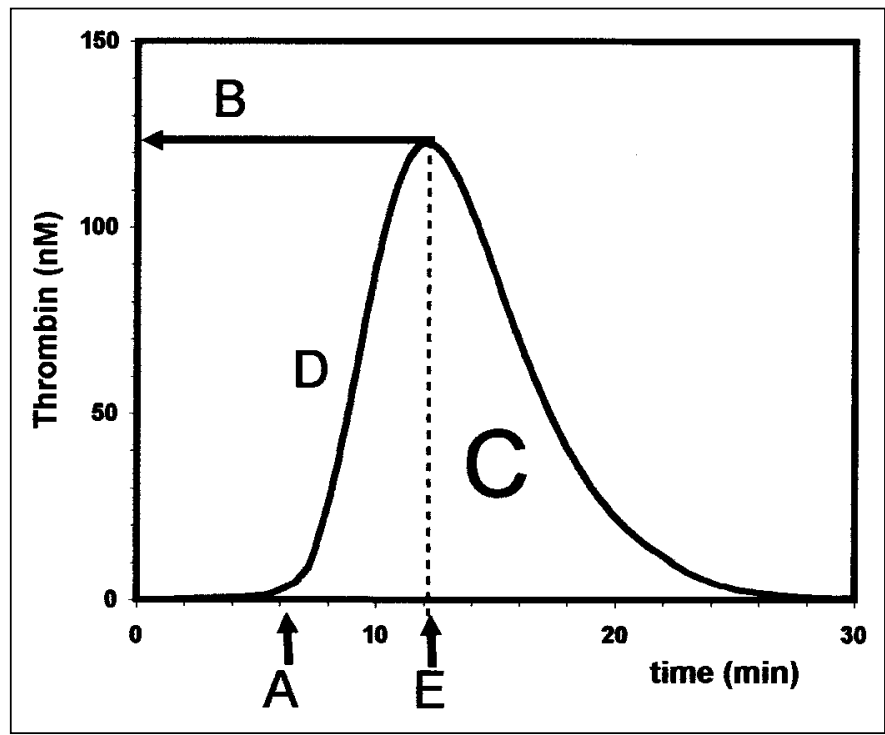

Figure I: The parameters of the thrombogram. A) Lag time (min), B) Peak height (nM), C) Endogenous thrombin potential (ETP) (= area under the curve)( $\mathrm{nM} \times \mathrm{min}), \mathrm{D})$ maximal rising slope (nM/min), E) time to peak ( $\mathrm{min})$.

any observable amounts of thrombin form (33) (Fig. 2) which, depending on the reaction conditions, activate one or more of the factors V, VIII, XI and platelets and thus prepare the scene for the full blown TG during the production (also called propagation-) phase (32). The reaction mechanism in the lag phase and the production phase are different. That is the reason why the lag- $(=$ clotting-) time does not automatically contain information on the amount of thrombin formed in the following peak (Fig. 3).

There is no sharp distinction between the production phase and the inactivation phase. As soon as thrombin appears it is scavenged by the plasma antithrombins, even during the lag phase. The velocity of inactivation increases proportionally with the thrombin concentration. At the peak, thrombin generation and decay are equally fast. Once past the peak, decay gains on prothrombin conversion, and somewhere in the down slope the latter will stop. This can be shown by calculating prothrombin conversion velocity from $\mathrm{TG}$ and the reaction constant of thrombin - antithrombin interaction $(34,35)$.

It is common knowledge that the pathway of thrombin formation is dependent upon the type and the amount of trigger used. The physiological trigger is tissue factor (TF). There is, however, no "physiological" concentration of tissue factor because, in vivo, it is not a soluble reactant but a component of membranes that are large compared to molecules. Reaction velocities are therefore determined by diffusion rather than by chemical interaction. The same is true for the trigger of the protein $\mathrm{C}$ system, thrombomodulin (TM). These two components, $\mathrm{TF}$ and TM, need to be added in order to substitute for the (wounded or intact) vessel wall. For practical reasons they are added in soluble form. The concentration of TF is chosen on basis of the section of the reaction mechanism that one wants to study (see below), that of TM so as to produce, in normal plasma, about $\sim 50 \%$ inhibition of the peak or of the ETP.

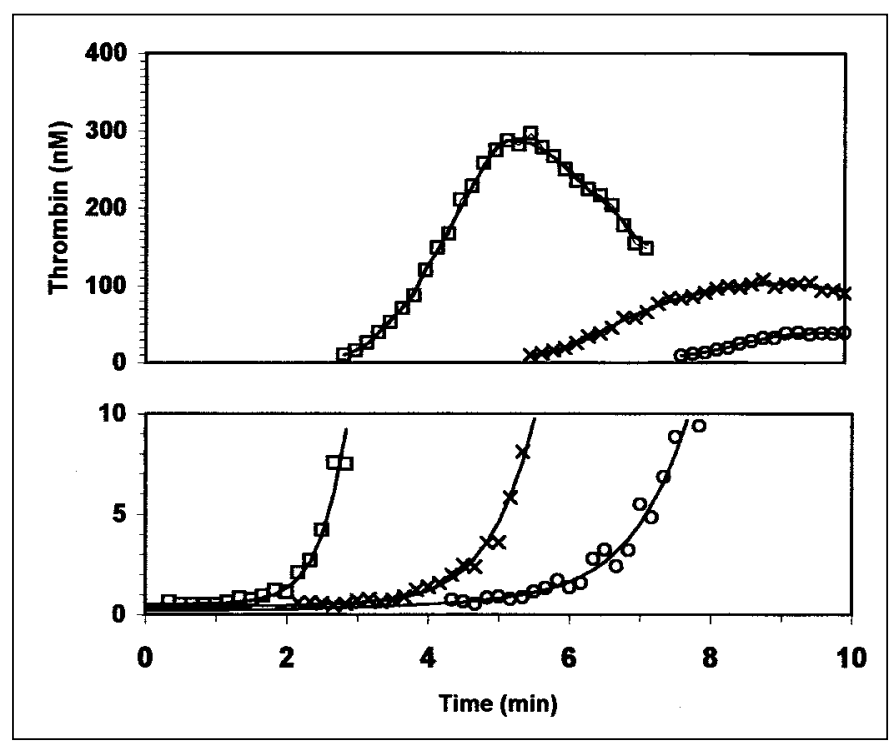

Figure 2: Thrombin generation in contact activated plasma, effect of heparin. $(\square)$ Control; $(X) 0.02 \mathrm{U} / \mathrm{ml}$ unfractionated heparin; (○) $0.03 \mathrm{U} / \mathrm{ml}$ unfractionated heparin.

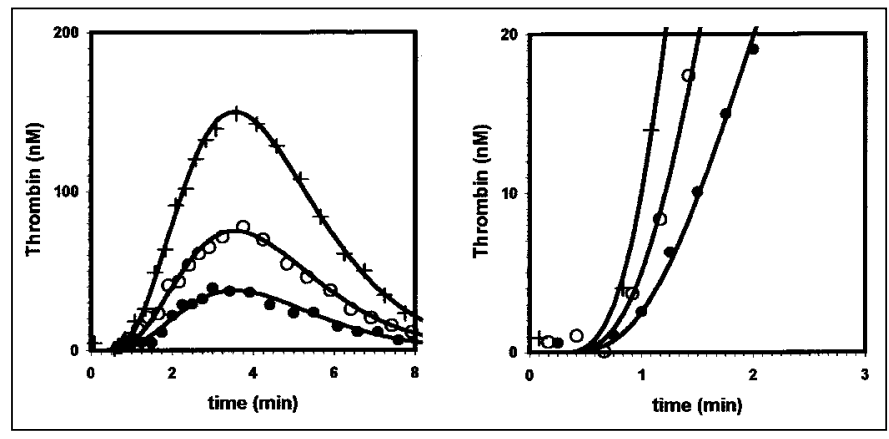

Figure 3: Thrombin generation triggered with 25 pM tissue factor, effect of heparin. $(X)$ Control; $(O) 0.02 \mathrm{U} / \mathrm{ml}$ unfractionated heparin; (๑) $0.03 \mathrm{U} / \mathrm{ml}$ unfractionated heparin.

In PPP, in the presence of $\sim 4 \mu \mathrm{M}$ procoagulant phospholipids and at high concentrations of TF $(>10 \mathrm{pM})$, the factor VIII, IX and XI -dependent reactions are bypassed. Under the same conditions but at intermediate concentrations $(2-5 \mathrm{pM})$ of TF, TG is dependent upon the concentration of factors VIII and IX, and at yet lower concentrations factor XI will start to play a role (36). The amount of TM that inhibits TG by $50 \%$ decreases with decreasing TF concentration. This stands to reason because TM needs to react with thrombin before APC can be formed. At high TF concentration, TG can be so fast that it is over before enough APC can be formed to delimit prothrombinase action. Adding soluble TF and TM is about as close as we can come to the in-vivo situation at the moment. However, it remains an artificial construct. TF and TM are present in the same solution here, whereas in vivo they are membrane-bound in different compartments, TF in the wound, and TM on the adjacent intact endothelium. 


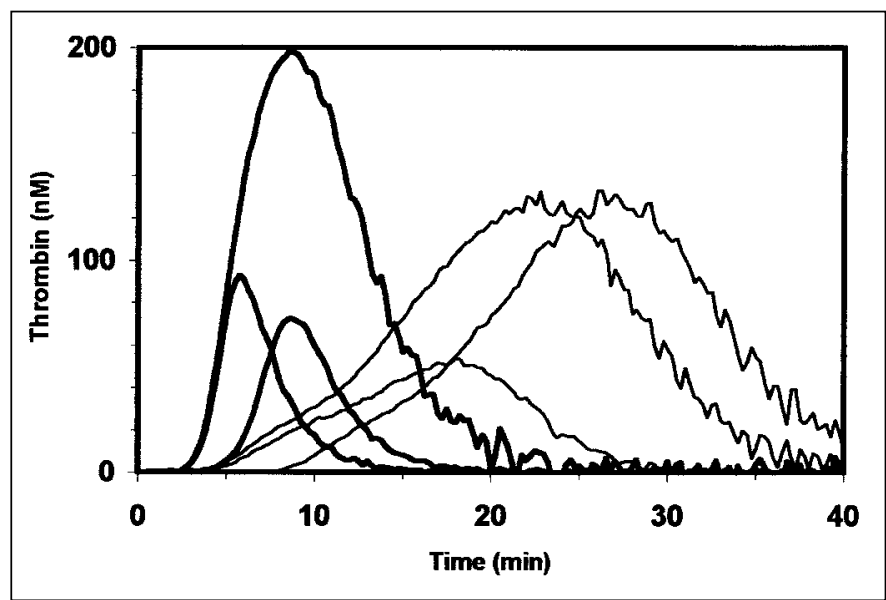

Figure 4: Thrombin generation in PPP and in PRP, effect of rTM ( $10 \mathrm{nM}$ ) and APC (10 nM). Fat lines: PPP, triggered with 5 PM of TF; lean lines PRP, triggered with 0.5 PM of TF. The small peak with the same lag-time as the uninhibited TG is that with added TM. Addition of APC increases the lag-time. Note that platelets appear to induce a resistance to APC but not to TM.

\section{Normal TG in PRP, the roles of fibrin(-ogen)}

TG in PPP always requires procoagulant phospholipids to be present. At the phospholipid-solute interface factors Xa and Va adsorb to form prothrombinase (37) and factors IXa and VIIIa to form tenase (38). The surface also serves to "funnel" the substrates (prothrombin and factor $\mathrm{X}$ ) to these enzyme complexes (39). If TG is observed in PPP without added phospholipids, this is most often due to contamination with platelets or cell remnants during plasma preparation. In carefully prepared plasma it indicated the presence of procoagulant microparticles. In PRP, the platelets provide the procoagulant phospholipids. Platelet activation that is important enough to cause a prolonged rise of intracellular $\mathrm{Ca}^{++}$makes platelets lose the natural asymmetry of their plasma membrane ("scrambling"). Thus, the outside of the platelet enriches in the procoagulant phospholipids phosphatidyl serine (PS) and phosphatidyl ethanolamine (PE) that are normally found at the inside (19). This turns the platelet surface into a two-dimensional reaction compartment, in which adsorbed clotting factors generate thrombin far more efficiently than in free solution $(40,41)$. Also, procoagulant vesicles are shed from the membrane of such activated platelets. Hence, TG in PRP depends upon platelet activation equally as much as on the plasmatic clotting factors. In vivo, there are two other sources of procoagulant phospholipids. These are circulating procoagulant microparticles that tend to crowd on a damaged site (42-44) as well as damaged or apoptotic cells that have lost the normal asymmetry of their membrane $(45,46)$.

As soon as a fibrin web forms, platelets, but also vesicles, adhere to its fibres (47). This ensures that thrombin is generated on membrane structures that are not able to move in solution. Under these conditions, it is not the chemical reaction velocities, but rather the diffusional transport to and from the membrane structures on the fibres which determine the velocity of TG. As clotting takes place, TG velocity thus shifts from chemical to diffu- sional control (48-50). When no fibrin can form, chemical kinetics remain in force, so the bulk of thrombin is formed in an essentially different manner in the presence and absence of fibrin. Another effect of the presence of fibrinogen is that it attenuates the formation of $\alpha_{2}$ macroglobulin-thrombin ( $\alpha_{2} \mathrm{M}$-thrombin) (Fig. 5).

Collagen and thrombin are the classical triggers for the platelet procoagulant reaction (19), so a role of the collagen receptors (GPIaIIa, GPVI) and thrombin receptors (PAR 1,4) was to be expected. Surprisingly, the fibrinogen receptor GPIIb/IIIa was involved (51), not least because it revealed that drugs conceived as aggregation inhibitors, such as abciximab, diminish TG in PRP.

Another unexpected observation was that a clot, as such, provokes procoagulant activity in platelets $(52,53)$. A snake venom enzyme such as Arvin does not play a role on the platelet or the coagulation system apart from the fact that it clots fibrinogen. Bringing about a clot with Arvin, quite unexpectedly, was found to trigger TG in PRP but not in PPP. The underlying mechanism appeared to be that polymerising fibrin interacts with $\mathrm{vWF}$ and modifies it in the same way as adsorption onto collagen or shear stress does. The modified vWF then via GP1b triggers the platelet procoagulant activity $(54,55)$. In this way fibrin takes over the role of collagen as soon as platelets cover the collagen surface and fibrin forms in the aggregate. Clotting apparently is not the closing act of haemostasis but it is a dynamic part of the haemostatic process. This also explains why thrombin becomes increasingly important the less collagen is exposed (22).

This fibrin-vWF-GP1b mechanism has been verified by showing that TG is diminished in the PRP (but not in the PPP) of hypofibrinogenaemia, in mild von Willebrand disease and in patients with Bernard-Soulier syndrome (in which functional GP1b is congenitally lacking). It reveals a third function of vWF, that not only acts as a "glue" for platelets onto matrix proteins and as a carrier of factor VIII but, in PRP, also contributes to activation of the procoagulant function of platelets and thus can be called a clotting factor in its own right.

\section{TG and thrombosis risk}

The pivotal role of thrombin in venous thrombotic disease goes undisputed [e.g. (56)]. This is directly reflected in medical practice: treatment and prevention of venous thrombosis require drugs that diminish thrombin activity in one way or another. This is done by either impeding prothrombin synthesis (vitamin $\mathrm{K}$ antagonists), increasing antithrombin activity (heparins), or by inhibiting thrombin directly (hirudin and small-molecular-weight reversible inhibitors). Increased formation of thrombin in PPP always induces a risk of venous thrombosis, whether it is due to deficiency of antithrombin (57), an excess of prothrombin (58), or to any other cause. Disorders in the protein $\mathrm{C}$ pathway (deficiency of proteins $\mathrm{S}$ and $\mathrm{C}$, factor $\mathrm{V}_{\text {Leiden }}$ ) increase $\mathrm{TG}$ as such and becomes particularly obvious if the protein $\mathrm{C}$ pathway is activated by thrombomodulin (Fig. 4). The thrombotic tendency induced by oral contraceptives can be explained by the increase of TG caused by an acquired resistance to activated protein C (APC) (59-61) possibly combined with other changes $(62,63)$. 
Particularly interesting is the lupus anticoagulant. This antibody causes an increase of the lag time of thrombin formation, i.e. of the clotting time, and is thus deemed "anticoagulant". It also brings about an important resistance to the activity of the protein $\mathrm{C}$ system and hence an increased TG in the presence of thrombomodulin (64). This again underlines that $\mathrm{TG}$ during the lag time is a different process from that in the production phase but that it is the latter that governs the thrombotic tendency. The "LAC paradox", i.e. prolonged clotting times together with a thrombotic tendency, thus disappears as soon as one resorts to TG.

The role of the plasmatic thrombin generating system is much more evident in venous than in arterial disease. There are arguments to surmise that thrombin plays a part in arterial thrombosis as well $(25,65-67)$. Excess amounts of factors II, VIII and VII have been found to correlate with the occurrence of myocardial infarction. Also, higher than normal levels of vWF increase TG and are a risk factor for arterial thrombosis (68-74). In a sub-population of young stroke patients $(\sim 30 \%)$, both TG in PRP and VWF have been shown to be significantly higher than normal (75). Clinical trials have shown that vitamin K antagonists $(76)$ as well as heparins $(77,78)$ decrease the reoccurrence rate of myocardial infarction. "Antiplatelet" drugs derive at least part of their effect by inhibiting TG in PRP $(14,15,51)$. Inversely, aspirin has been shown to be beneficial also in venous thrombosis (79). Like the distinction between primary and secondary haemostasis, the classical view that arterial thrombosis is due to the platelet and venous thrombosis to clotting seems to become less evident. Nevertheless, the precise role of thrombin generation in arterial thrombotic disease remains enigmatic. We surmise that much can be learned from the study of thrombin generation in PRP in relation to arterial disease.

\section{TG and bleeding}

It has been demonstrated for the haemophilias (VIII, IX or XI) as well as for all rare clotting factor deficiencies (II, V, VII, X, XII) that TG is diminished and that a clinical bleeding tendency is seen as soon as TG drops below $20 \%$ of normal $(9,36,80,81)$. In haemophilia A, not only does infusion of factor VIII or administration of DDAVP augment TG (82), but also inhibitor bypassing therapy with products containing prothrombin and/or factor VII (83-87). Any overshoot of antithrombotic therapy (-prevention) invariably carries a risk of bleeding, because antithrombotics act through diminution of TG.

Severe thrombopenia $(<50.000 \mu \mathrm{l}-1)$ causes decreased TG as well as the Glanzmann (51) and Bernard-Soulier (52) thrombopathies. As mentioned above, in von Willebrand's disease, TG in PRP is significantly impaired. The defect is much more pronounced in PRP than in PPP, which indicates that it can not be explained by the concomitant deficiency of factor VIII. The discrepancy between TG in PPP and in PRP in von Willebrand disease has not yet been explored but is a potentially useful diagnostic possibility.

One of the reasons that a low ETP causes a bleeding tendency is likely due to the fact that the amount of thrombin formed determines the amount of fibrinolysis inhibitor TAFI that is generated (88). Low TG therefore causes increased fibrinolysis. This

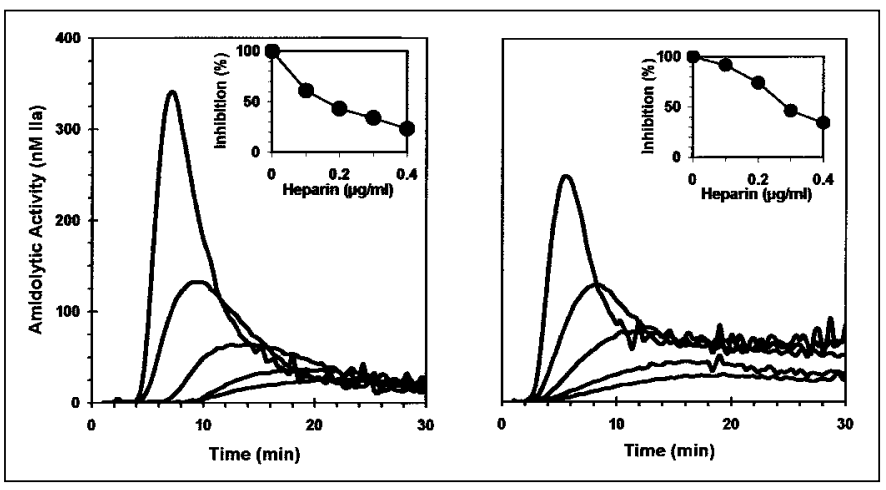

Figure 5: Amidolytic activity in PPP with (left) and without (right) fibrinogen, influence of heparin. Inset: Inhibition of thrombin generation in $\%$ as a function of the heparin concentration $(0.1,0.2$, 0.3 and $0,4 \mu \mathrm{g} / \mathrm{ml})$.

is likely to be the explanation for the fibrinolytic character of much of the bleeding in haemophilia and would explain the beneficial effect of antifibrinolytic agents [e.g. (89)].

\section{How can the thrombin-forming capacity of blood be assessed?}

Classically, thrombograms were obtained by timed subsampling of aliquots from clotting blood or plasma onto a solution of diluted bovine plasma (without $\mathrm{Ca}^{++}$) and by assessing the thrombin concentration in the sample from the clotting time observed (1). The procedure, which takes about one man-hour per curve, involves a score of stopwatches and extraordinary dexterity. Subsampling onto a chromogenic thrombin substrate (35) allows automatic recording of the sampling time and semi-automatic measurement of the thrombin activities. In this way, several parallel experiments can be done, which made it possible to recognise the role of various platelet receptors and fibrinogen (51-53).

The use of small MW substrates also introduces a complication because of the exceptional way in which $\alpha_{2}$ macroglobulin $\left(\alpha_{2} \mathrm{M}\right)$ inhibits thrombin: After initial proteolytic interaction of thrombin with a "bait"-region, thrombin is bound in a niche of $\alpha_{2} \mathrm{M}$ so that, through steric hindrance, no physiological substrates can be split anymore. Small substrates can still be attacked, however. The total amidolytic activity measured during TG is the sum of free thrombin and the $\alpha_{2} \mathrm{M}$-thrombin complex (Fig. 5). The velocity of the formation of the complex is in good approximation proportional to the concentration of free thrombin. Therefore, the amount of $\alpha_{2} \mathrm{M}$-thrombin in serum is proportional to the integral of the thrombogram, i.e. to the ETP. A simple algorithm, executable in any spreadsheet program, allows one to split the curve of amidolytic activity into its free-thrombin and $\alpha_{2}$ M-thrombin parts [see further (90)]. In defibrinated plasma, the $\alpha_{2} \mathrm{M}$-thrombin end level after TG can be used to estimate the effect of APC. Rosing et al. (60) used this approach to demonstrate the acquired APC-resistance induced by oral contraceptives.

The next step in simplifying TG measurement was to add the chromogenic substrate directly to the clotting plasma. This can 


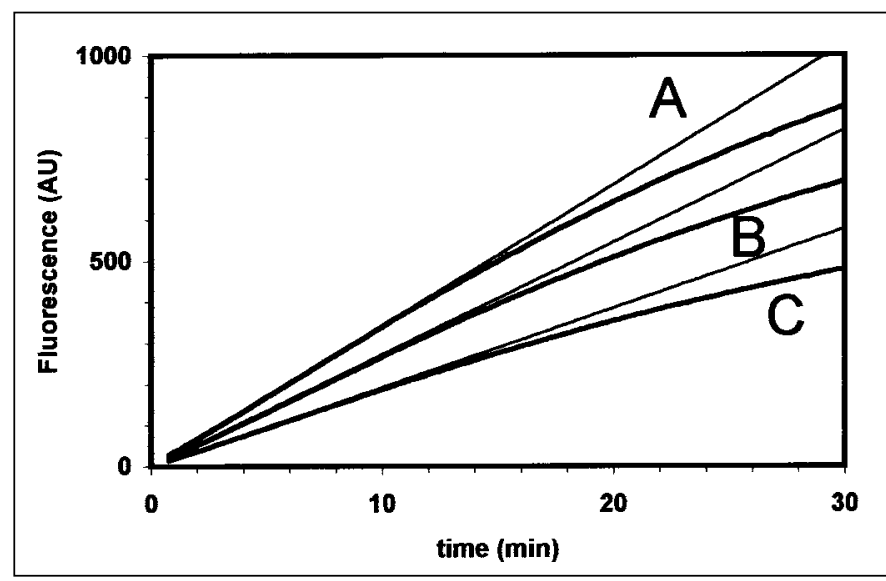

Figure 6: The fluorescence evolving from $100 \mathrm{nM}$ thrombin activity in three different plasmas. The stable thrombin activity was obtained through addition of $\alpha 2 \mathrm{M}$-thrombin. A) Normal pooled plasma; B) Haemolytic plasma (0.4\% haemolysis); C) Icteric plasma.

not seriously be attempted with the normal high affinity substrates because they bind thrombin so tightly that they act as potent thrombin inhibitors, so that the normal thrombin generation mechanism, with its many thrombin-driven feedback reactions, will be profoundly disturbed. Once thrombin is formed, the substrate is converted very quickly so the decay phase seen is due to substrate exhaustion and not to thrombin disappearance. The resulting curves have a superficial similarity to TG curves but none of the parameters of the real course of thrombin in time can be read from them.

Correct measurement of the clotting function requires substrates that do not significantly interfere with the normal prothrombin conversion process and have such kinetic properties that, during the whole process, the velocity of product formation is in good approximation proportional to the prevailing concentration of thrombin. Chromogenic substrates of this type are available and allow the monitoring of thrombin activity photometrically (91). Although they do not interfere with normal prothrombin conversion, they will, like any thrombin substrate, compete with the plasmatic antithrombins for the active site of thrombin. Therefore, thrombin decay is always slowed down and the measured ETP is consequently artificially augmented. The magnitude of this effect can be easily calculated and adjusted for [the real ETP equals $\mathrm{Km} /(\mathrm{Km}+\mathrm{S})$ times the observed ETP].

As OD measurement is disturbed by light scattering, clot formation has to be avoided when chromogenic substrates are used, either by defibrination or by adding polymerization inhibitors. Defibrination can be carried out with suitable snake venom enzymes (e.g. Arvin). However, platelets are removed together with the fibrin, so chromogenic continuous methods are restricted to defibrinated PPP. Defibrination abolishes the role of diffusion in TG and significantly changes its kinetics (see above). As discussed, the effect of added heparin, for example, is quite different in normal plasma and defibrinated plasma (Fig. 5). Polymerisation inhibitors may interfere with normal prothrombin conversion and alter the behaviour of platelets (unpublished results).

Fluorescence can be measured in turbid media, so the use of fluorogenic substrates abolishes the drawbacks of defibrination or inhibition of polymerisation (92). However, it introduces other problems. Firstly, plasma adsorbs a significant and variable amount of the light, so that the signal from plasma, even at 2:5 dilution, is on the mean $\sim 65 \%$ of that in buffer. Worse is the large variation of this property between apparently normal plasmas: $\sim 15 \%$. This means that the reaction velocities measured in plasma can not be standardised by comparison to buffer, or by comparison to another plasma. Or, if thrombin activity in buffer is used as a standard [as for example in $(86,93,94)$ ], thrombin generation will be $\sim 30 \%$ underestimated and $\sim 15 \%$ is added to the experimental variation

Using the available substrates, the proportionality between reaction velocity and product formation can not be maintained during the experiment and also the fluorescent signal is not proportional to the concentration of fluorophore in the solution. As a result, the same amount of thrombin activity causes a far greater increase of signal at the beginning of the experiment than towards the end. In other words, the calibration factor is a function of the amount of fluorescent product already present. Moreover, the readings are very sensitive to the colour of the plasma, notably to minimal haemolysis (Fig. 6).

The three drawbacks of fluorescent methods have to be dealt with by continuous, individual calibration of every sample. In this technique, a fixed amount of constant thrombin activity is added to a parallel sample of the same plasma. From the resulting curve, the calibration factor at any level of fluorescence is read and the exact thrombin concentration in the sample where TG is taking place can be calculated. Using continuous calibration significantly reduces the intra-individual experimental error from $>15 \%$ to $\sim 5 \%$.

Methods that use fibrinogen as an indicator substance (95-97) are ideal for the determination of the length of the initiation phase, i.e. the clotting time, especially as no foreign substances have to be added. When the mechanical properties of the clot serve as an indicator, an additional advantage is that whole blood can be used directly (98). Alternatively, the turbidity of the clot in plasma can be measured (99). The greatest drawback of fibrinogen-based methods is that fibrinogen is consumed long before thrombin formation is over so that no information can be obtained on the stages of thrombin generation beyond the very beginning of the production (= propagation) phase. A second drawback is that there is no known relation between mechanical properties or turbidity and the activity of thrombin, so that even the information on this first stage of TG can not be quantified in terms of thrombin concentrations. This is all the more serious when curves are constructed that can easily be mistaken for real thrombograms (100-102) as a result of mathematical transformations that do not improve the content of information in any way. The question remains whether the observed signals provide more useful information than the clotting time does.

It is perhaps now appropriate to remark that a multitude of different methods allow scores of measurable properties of blood (-plasma) that change as a result of the formation of thrombin and/or fibrin. Parameters can be obtained, e.g. with unsuitable substrates, or can be derived from the mechanical properties of forming fibrin (clotting times, thrombelastogram) or from its turbidity (wave form analysis). Other parameters arise when data from suitable substrates are inadequately calibrated etc. Often it 
will be possible to correlate such changes to a clinical picture (103). There is a respectable clinical tradition of linking misunderstood phenomena to clinical diagnosis (e.g. spider naevi > liver cirrhosis). This may also extend to laboratory observations. Erythrocyte sedimentation velocity started out as a pregnancy test. One can not deny the use of such correlations. Nevertheless, laboratory variables, in some way resulting from thrombin action, are better abandoned now that correct assessment of this physiological function has become available.

\section{Perspectives}

From the above it looks as if the thrombograms might be an overall function test of the haemostatic-thrombotic system. In the present stage of development, the focus is primarily to explore its possibilities. It will inevitably be followed by a phase in which the merits of the test will be critically explored and the limits of its use defined. A few domains in which we expect the test to be useful are mentioned below. Future research will show which of the present projections will be realized.

A: Hypercoagulability and the risk of thrombosis: Following on from the observation that all known risk factors increase TG, one might infer that increased TG is a risk factor as such, independent of its cause. This is reinforced by the observation that TG increases with age in a population without known risk factors $(104,105)$. The large inter-individual variation of the ETP in the normal population (CV 16\%) makes it not uncommon for a normal person to generate twice as much thrombin as any other equally normal person! Larger epidemiological studies seem justified to see whether such differences influence the occurrence of thrombosis. A relation between TG in PPP and venous thrombosis appears quite likely, especially when the function of the protein $\mathrm{C}$ system is probed by adding TM. The subject of thrombin generation in PRP and arterial thrombosis currently remains completely unexplored.

B: Control of antithrombotic therapy: At the moment, different tests are being used for the control of different antithrombotics. Diminution of TG is a common denominator of all anticoagulation, including that by low-molecular-weight heparins and heparin likes that hardly influence any clotting test. It also moni- tors the combined effect of oral anticoagulation and heparins, as in the treatment of venous thrombosis.

The real challenge in this domain, however, is investigating the effect of anticoagulant drugs and platelet inhibitors on TG in PRP. Does platelet inhibition enhance the effect of heparin because it inhibits the release of platelet factor 4? Is the relative APC-resistance of PRP enhanced by oral anticoagulation?; etc. etc. The (clinical-) pharmacology of antithrombotic drugs acquires a new playground now that experiments on the isolated target organ blood are possible.

C: Closely related to the previous item is the role that TG may play in finding and testing of new antithrombotics. We dare to surmise that a candidate drug that inhibits TG by about $40-60 \%$ for 24 hours per day, will have an antithrombotic effect and will not cause bleeding. As a screening test TG may significantly reduce the number of experimental animals required to establish the efficacy of new drugs. It may also be useful to monitor a new drug in human experiments and clinical trials. It might even lead to the discovery of drugs that can hardly be found in another way. One might dream, for example, of an orally available heparin-like compound which acts via heparin cofactor II (HCII). Because there is only $\sim 1 \mu \mathrm{M}$ of $\mathrm{HCII}$ in plasma, complete activation will never scavenge all the thrombin that can be formed from prothrombin, presently $\sim 2 \mu \mathrm{M}$, so overdosage is impossible. Such a drug could not be detected with any clotting test but will immediately show its effect in a TG experiment.

D: In haemophilia the discrepancy between factor VIII level and clinical bleeding tendency remains to be solved. Pilot experiments have shown that TG can be used for therapeutic decisions in inhibitor bypassing therapy (83). If it could be proven that the level of TG - in PPP or in PRP - indeed indicates the bleeding risk, not only would clinical decision making be much easier, but one could also make a more economic use of very costly preparations.

E: Diagnosis of von Willebrand disease: Because vWF is required for the development of full procoagulant power in platelets, a discrepancy between TG in PPP and PRP is systematically found in von Willebrand disease. This could be explored as a means of diagnosis.

\section{References}

1. Biggs R, Macfarlane RG. Human Blood Coagulation and its Disorders. Oxford: Blackwell, 1953.

2. Mann KG, Brummel K, Butenas S. What is all that thrombin for? J Thromb Haemost 2003; 1: 1504-14.

3. Barrowcliffe TW, Gray E, Kerry PJ, et al. Triglyceride-rich lipoproteins are responsible for thrombin generation induced by lipid peroxides. Thromb Haemost 1984; 52: 7-10.

4. Barrowcliffe TW, Gutteridge JM, Dormandy TL. The effect of fatty-acid autoxidation products on blood coagulation. Thromb Diath Haemorrh 1975; 33: 271-7.

5. Josso F, Monasterio de Sanchez J, Lavergne JM, et al. Congenital abnormality of the prothrombin molecule (factor II) in four siblings: prothrombin Barcelona. Blood 1971; 38: 9-16.

6. Josso F, Rio Y, Beguin S. A new variant of human prothrombin: prothrombin Metz, demonstration in a family showing double heterozygosity for congenital hypoprothrombinemia and dysprothrombinemia. Haemostasis 1982; 12: 309-16.

7. Hemker HC, Giesen P, AlDieri R, et al. The calibrated automated thrombogram (CAT): a universal routine test for hyper- and hypocoagulability. Pathophysiol Haemost Thromb 2002; 32: 249-53.

8. Aledort LM. Why thrombin generation? From bench to bedside. Pathophysiol Haemost Thromb 2003; 33: $2-3$.

9. Siegemund T, Petros S, Siegemund A, et al. Thrombin generation in severe haemophilia A and B: the endogenous thrombin potential in platelet-rich plasma. Thromb Haemost 2003; 90: 781-6.

10. Marongiu F, Biondi G, Sorano GG, et al. Bleeding time is prolonged during oral anticoagulant therapy. Thromb Res 1990; 59: 905-12.
11. Lavelle SM, MacIomhair M. Bleeding times and the antithrombotic effects of high-dose aspirin, hirudin and heparins in the rat. Ir J Med Sci 1998; 167: 216-20. 12. Sambrano GR, Weiss EJ, Zheng YW, et al. Role of thrombin signalling in platelets in haemostasis and thrombosis. Nature 2001; 413: 74-8.

13. Jensen AH, Beguin S, Josso F. Factor V and VIII activation ,,in vivo“ during bleeding. Evidence of thrombin formation at the early stage of hemostasis. Pathol Biol (Paris) 1976; 24 (Suppl): 6-10.

14. Kessels H, Beguin S, Andree H, et al. Measurement of thrombin generation in whole blood--the effect of heparin and aspirin. Thromb Haemost 1994; 72: 78-83. 15. Musial J, Radwan J, Szczeklik A. Aspirin delays thrombin generation in vitro through interaction with platelet phospholipids. Thromb Res 1997; 85: 367-8. 16. Musial J, Swadzba J, Jankowski M, et al. Thrombin generation measured ex vivo following microvascular in- 
jury is increased in SLE patients with antiphospholipidprotein antibodies. Thromb Haemost 1997; 78: 1173-7. 17. Szczeklik A. Inhibition of thrombin generation by aspirin. Thromb Haemost 1994; 72: 988-9.

18. Celi A, Merrill-Skoloff G, Gross P, et al. Thrombus formation: direct real-time observation and digital analysis of thrombus assembly in a living mouse by confocal and widefield intravital microscopy. JThromb Haemost 2003; 1: 60-8.

19. Bevers EM, Comfurius P, van Rijn JL, et al. Generation of prothrombin-converting activity and the exposure of phosphatidylserine at the outer surface of platelets. Eur J Biochem 1982; 122: 429-36.

20. Beguin S, Lindhout T, Hemker HC. The effect of trace amounts of tissue factor on thrombin generation in platelet rich plasma, its inhibition by heparin. Thromb Haemost 1989; 61: 25-9.

21. Giesen PL, Rauch U, Bohrmann B, et al. Bloodborne tissue factor: another view of thrombosis. Proc Natl Acad Sci USA 1999; 96: 2311-5.

22. Furie BC, Furie B. Tissue factor pathway vs. collagen pathway for in vivo platelet activation. Blood Cells Mol Dis 2006.

23. Jackson CM, Esnouf MP, Lindahl TL. A critical evaluation of the prothrombin time for monitoring oral anticoagulant therapy. Pathophysiol Haemost Thromb 2003; 33: 43-51.

24. Fressinaud E, Sakariassen KS, Rothschild C, et al. Shear rate-dependent impairment of thrombus growth on collagen in nonanticoagulated blood from patients with von Willebrand disease and hemophilia A. Blood 1992; 80: 988-94.

25. Gast A, Tschopp TB, Baumgartner HR. Thrombin plays a key role in late platelet thrombus growth and/or stability. Effect of a specific thrombin inhibitor on thrombogenesis induced by aortic subendothelium exposed to flowing rabbit blood. Arterioscler Thromb 1994; 14: 1466-74.

26. Inauen W, Baumgartner HR, Bombeli T, et al. Doseand shear rate-dependent effects of heparin on thrombogenesis induced by rabbit aorta subendothelium exposed to flowing human blood. Arteriosclerosis 1990; 10: 607-15.

27. Weiss EJ, Hamilton JR, Lease KE, et al. Protection against thrombosis in mice lacking PAR3. Blood 2002; 100: $3240-4$

28. Anand M, Rajagopal K, Rajagopal KR. A model for the formation and lysis of blood clots. Pathophysiol Haemost Thromb 2005; 34: 109-20.

29. Ermakova EA, Panteleev MA, Shnol EE. Blood coagulation and propagation of autowaves in flow. Pathophysiol Haemost Thromb 2005; 34: 135-42.

30. Fogelson AL, Tania N. Coagulation under flow: the influence of flow-mediated transport on the initiation and inhibition of coagulation. Pathophysiol Haemost Thromb 2005; 34: 91-108.

31. Lobanov AI, Starozhilova TK. The effect of convective flows on blood coagulation processes. Pathophysiol Haemost Thromb 2005; 34: 121-34.

32. Butenas S, DiLorenzo ME, Mann KG. Ultrasensitive fluorogenic substrates for serine proteases. Thromb Haemost 1997; 78: 1193-201.

33. Hemker HC, Beguin S. The mode of action of heparins in vitro and in vivo. Adv Exp Med Biol 1992; 313: 221-30.

34. Beguin S, Kessels H, Dol F, et al. The consumption of antithrombin III during coagulation, its consequences for the calculation of prothrombinase activity and the standardisation of heparin activity. Thromb Haemost 1992; 68: 136-42.

35. Hemker HC, Willems GM, Beguin S. A computer assisted method to obtain the prothrombin activation velocity in whole plasma independent of thrombin decay processes. Thromb Haemost 1986; 56: 9-17.
36. Keularts IM, Zivelin A, Seligsohn U, et al. The role of factor XI in thrombin generation induced by low concentrations of tissue factor. Thromb Haemost 2001; 85: $1060-5$.

37. Hemker HC, Esnouf MP, Hemker PW, et al. Formation of prothrombin converting activity. Nature 1967; 215: 248-51.

38. Hemker HC, Kahn MJ. Reaction sequence of blood coagulation. Nature 1967; 215: 1201-2.

39. Giesen PL, Willems GM, Hermens WT. Production of thrombin by the prothrombinase complex is regulated by membrane-mediated transport of prothrombin. J Biol Chem 1991; 266: 1379-82.

40. Nesheim ME, Taswell JB, Mann KG. The contribution of bovine Factor V and Factor Va to the activity of prothrombinase. J Biol Chem 1979; 254: 10952-62.

41. Rosing J, Tans G, Govers-Riemslag JW, et al. The role of phospholipids and factor $\mathrm{Va}$ in the prothrombinase complex. J Biol Chem 1980; 255: 274-83.

42. Falati S, Liu Q, Gross P, et al. Accumulation of tissue factor into developing thrombi in vivo is dependent upon microparticle P-selectin glycoprotein ligand 1 and platelet P-selectin. J Exp Med 2003; 197: 1585-98. 43. Gross PL, Furie BC, Merrill-Skoloff G, et al. Leukocyte-versus microparticle-mediated tissue factor transfer during arteriolar thrombus development. J Leukoc Biol 2005; 78: 1318-26.

44. Sim D, Flaumenhaft R, Furie B, et al. Interactions of platelets, blood-borne tissue factor, and fibrin during arteriolar thrombus formation in vivo. Microcirculation 2005; 12: 301-11.

45. Bombeli T, Karsan A, Tait JF, et al. Apoptotic vascular endothelial cells become procoagulant. Blood 1997; 89: 2429-42.

46. Flynn PD, Byrne CD, Baglin TP, et al. Thrombin generation by apoptotic vascular smooth muscle cells. Blood 1997; 89: 4378-84.

47. Siljander P, Carpen O, Lassila R. Platelet-derived microparticles associate with fibrin during thrombosis. Blood 1996; 87: 4651-63.

48. Hemker HC, de Smedt E, Hemker PW. Mathematical and biological models of blood coagulation. A rebuttal. J Thromb Haemost 2006; 4: 710-1.

49. Hemker HC, E DES, Hemker PW. During coagulation, thrombin generation shifts from chemical to diffusional control. J Thromb Haemost 2005; 3: 2399-400. 50. Mann KG, Brummel-Ziedins $\mathrm{K}$, Orfeo $\mathrm{T}$, et al. Models of blood coagulation. Blood Cells Mol Dis 2006.

51. Reverter JC, Beguin S, Kessels H, et al. Inhibition of platelet-mediated, tissue factor-induced thrombin generation by the mouse/human chimeric 7E3 antibody. Potential implications for the effect of c7E3 Fab treatment on acute thrombosis and „clinical restenosis“. J Clin Invest 1996; 98: 863-74.

52. Beguin S, Keularts I, Al Dieri R, et al. Fibrin polymerization is crucial for thrombin generation in platelet-rich plasma in a VWF-GPIb-dependent process, defective in Bernard-Soulier syndrome. J Thromb Haemost 2004; 2: 170-6.

53. Beguin $S$, Kumar R. Thrombin, fibrin and platelets: a resonance loop in which von Willebrand factor is a necessary link. Thromb Haemost 1997; 78: 590-4.

54. Kumar R, Beguin S, Hemker HC. The influence of fibrinogen and fibrin on thrombin generation--evidence for feedback activation of the clotting system by clot bound thrombin. Thromb Haemost 1994; 72: 713-21.

55. Kumar R, Beguin S, Hemker HC. The effect of fibrin clots and clot-bound thrombin on the development of platelet procoagulant activity. Thromb Haemost 1995; 74: 962-8.

56. Nossel HL, Yudelman I, Canfield RE, et al. Measurement of fibrinopeptide A in human blood. J Clin Invest 1974; 54: 43-53.
57. Wielders S, Mukherjee M, Michiels J, et al. The routine determination of the endogenous thrombin potential, first results in different forms of hyper- and hypocoagulability. Thromb Haemost 1997; 77: 629-36. 58. Kyrle PA, Mannhalter C, Beguin S, et al. Clinical studies and thrombin generation in patients homozygous or heterozygous for the G20210A mutation in the prothrombin gene. Arterioscler Thromb Vasc Biol 1998; 18: 1287-91.

59. Nicolaes GA, Thomassen MC, Tans G, et al. Effect of activated protein $\mathrm{C}$ on thrombin generation and on the thrombin potential in plasma of normal and APCresistant individuals. Blood Coagul Fibrinolysis 1997; 8: 28-38.

60. Rosing J, Tans G, Nicolaes GA, et al. Oral contraceptives and venous thrombosis: different sensitivities to activated protein $\mathrm{C}$ in women using second- and third-generation oral contraceptives. Br J Haematol 1997; 97: 233-8.

61. Rotteveel RC, Roozendaal KJ, Eijsman L, et al. The influence of oral contraceptives on the time-integral of thrombin generation (thrombin potential). Thromb Haemost 1993; 70: 959-62.

62. Schubert L, Gibelli A, De Nicola P. Blood coagulation and fibrinolysis in patients treated with an anovulatory drug with estroprogestational action. Ann Ostet Ginecol Med Perinat 1968; 90: 48-58.

63. van Deijk WA, van Dam-Mieras MC, Muller AD, et al. Evaluation of a coagulation assay determining the activity state of factor VII in plasma. Haemostasis 1983; 13: 192-7.

64. Regnault V, Beguin S, Wahl D, et al. Thrombinography shows acquired resistance to activated protein $\mathrm{C}$ in patients with lupus anticoagulants. Thromb Haemost 2003; 89: 208-12.

65. Badimon L, Badimon JJ, Lassila R, et al. Thrombin regulation of platelet interaction with damaged vessel wall and isolated collagen type I at arterial flow conditions in a porcine model: effects of hirudins, heparin, and calcium chelation. Blood 1991; 78: 423-34.

66. Badimon JJ, Lettino M, Toschi V, et al. Local inhibition of tissue factor reduces the thrombogenicity of disrupted human atherosclerotic plaques: effects of tissue factor pathway inhibitor on plaque thrombogenicity under flow conditions. Circulation 1999; 99 1780-7.

67. Heras M, Chesebro JH, Webster MW, et al. Hirudin, heparin, and placebo during deep arterial injury in the pig. The in vivo role of thrombin in platelet-mediated thrombosis. Circulation 1990; 82: 1476-84.

68. Giroud M, Dutrillaux F, Lemesle M, et al. Coagulation abnormalities in lacunar and cortical ischemic stroke are quite different. Neurol Res 1998; 20: 15-8. 69. Gurfinkel E, Altman R, Scazziota A, et al. Importance of thrombosis and thrombolysis in silent ischaemia: comparison of patients with acute myocardial infarction and unstable angina. Br Heart J 1994; 71 : $151-5$.

70. Haider AW, Andreotti F, Thompson GR, et al Serum lipoprotein(a) level is related to thrombin generation and spontaneous intermittent coronary occlusion in patients with acute myocardial infarction. Circulation 1996; 94: 2072-6.

71. Martinez-Sales V, Vila V, Reganon E, et al. Elevated thrombotic activity after myocardial infarction: A 2-year follow-up study. Haemostasis 1998; 28: 301-6. 72. Soskin P, Mossard JM, Arbogast R, et al. Variation in von Willebrand's Factor according to the treatment of acute myocardial infarction: physiopathological and clinical implications. Eur Heart J 1994; 15: 479-82. 73. Soskin P, Wiesel ML, Mossard JM, et al. Potential thrombogenicity of coronary angioplasty compared with coronary angiography. Blood Coagul Fibrinolysis 1994; 5: 965-6. 
74. Tanaka M, Suzuki A. Hemostatic abnormalities in acute myocardial infarction as detected by specific blood markers. Thromb Res 1994; 76: 289-98.

75. Faber CG, Lodder J, Kessels F, et al. Thrombin generation in platelet-rich plasma as a tool for the detection of hypercoagulability in young stroke patients. Pathophysiol Haemost Thromb 2003; 33: 52-8.

76. A double-blind trial to assess long-term oral anticoagulant therapy in elderly patients after myocardial infarction. Report of the Sixty Plus Reinfarction Study Research Group. Lancet 1980; 2: 989-94.

77. Neri Serneri GG, Modesti PA, Gensini GF, et al. Randomised comparison of subcutaneous heparin, intravenous heparin, and aspirin in unstable angina. Studio Epoorine Sottocutanea nell'Angina Instobile (SESAIR) Refrattorie Group. Lancet 1995; 345: 1201-4. 78. Neri Serneri GG, Rovelli F, Gensini GF, et al. Effectiveness of low-dose heparin in prevention of myocardial reinfarction. Lancet 1987; 1: 937-42.

79. Prevention of pulmonary embolism and deep vein thrombosis with low dose aspirin: Pulmonary Embolism Prevention (PEP) trial. Lancet 2000; 355: 1295-302.

80. Al Dieri R, Peyvandi F, Santagostino E, et al. The thrombogram in rare inherited coagulation disorders: its relation to clinical bleeding. Thromb Haemost 2002; 88: 576-82.

81. Dargaud Y, Beguin S, Lienhart A, et al. Evaluation of thrombin generating capacity in plasma from patients with haemophilia A and B. Thromb Haemost 2005; 93: 475-80.

82. Keularts IM, Hamulyak K, Hemker HC, et al. The effect of DDAVP infusion on thrombin generation in platelet-rich plasma of von Willebrand type 1 and in mild haemophilia A patients. Thromb Haemost 2000; 84: 638-42.

83. Dargaud Y, Lienhart A, Meunier S, et al. Major surgery in a severe haemophilia A patient with high titre inhibitor: use of the thrombin generation test in the therapeutic decision. Haemophilia 2005; 11: 552-8.
84. Hedner U. Dosing with recombinant factor viia based on current evidence. Semin Hematol 2004; 41 35-9.

85. Hedner U. Mechanism of action of recombinant activated factor VII: an update. Semin Hematol 2006; 43 . S105-7.

86. Turecek PL, Varadi K, Keil B, et al. Factor VIII inhibitor-bypassing agents act by inducing thrombin generation and can be monitored by a thrombin generation assay. Pathophysiol Haemost Thromb 2003; 33 16-22.

87. Turecek PL, Varadi K, Schwarz HP. Update on the mechanism of action and future of activated prothrombin complex concentrates. Curr Hematol Rep 2004; 3 . 331-7.

88. Lisman T, Mosnier LO, Lambert T, et al. Inhibition of fibrinolysis by recombinant factor VIIa in plasma from patients with severe hemophilia A. Blood 2002; 99: $175-9$.

89. Lee AP, Boyle CA, Savidge GF, et al. Effectiveness in controlling haemorrhage after dental scaling in people with haemophilia by using tranexamic acid mouthwash. Br Dent J 2005; 198: 33-8; discussion 26.

90. Hemker HC, Beguin S. Thrombin generation in plasma: its assessment via the endogenous thrombin potential. Thromb Haemost 1995; 74: 134-8.

91. Hemker HC, Wielders S, Kessels H, et al. Continuous registration of thrombin generation in plasma, its use for the determination of the thrombin potential. Thromb Haemost 1993; 70: 617-24.

92. Hemker HC, Giesen PL, Ramjee M, et al. The thrombogram: monitoring thrombin generation in platelet-rich plasma. Thromb Haemost 2000; 83: 589-91.

93. Varadi K, Negrier C, Berntorp E, et al. Monitoring the bioavailability of FEIBA with a thrombin generation assay. J Thromb Haemost 2003; 1: 2374-80.

94. Varadi K, Turecek PL, Schwarz HP. Thrombin generation assay and other universal tests for monitoring haemophilia therapy. Haemophilia 2004; 10 (Suppl 2): $17-21$.
95. Hartert H. Thrombelastography, a method for physical analysis of blood coagulation. Z Gesamte Exp Med 1951; 117: 189-203.

96. Luddington RJ. Thrombelastography/thromboelastometry. Clin Lab Haematol 2005; 27: 81-90.

97. Velik-Salchner C, Schnurer C, Fries D, et al. Normal values for thrombelastography (ROTEM) and selected coagulation parameters in porcine blood. Thromb Res 2006; 117: 597-602.

98. Rivard GE, Brummel-Ziedins KE, Mann KG, et al. Evaluation of the profile of thrombin generation during the process of whole blood clotting as assessed by thrombelastography. J Thromb Haemost 2005; 3: 2039-43.

99. Downey C, Kazmi R, Toh CH. Novel and diagnostically applicable information from optical waveform analysis of blood coagulation in disseminated intravascular coagulation. Br J Haematol 1997; 98: 68-73. 100. Hvitfeldt Poulsen L, Christiansen K, Sorensen B, et al. Whole blood thrombelastographic coagulation profiles using minimal tissue factor activation can display hypercoagulation in thrombosis-prone patients. Scand J Clin Lab Invest 2006; 66: 329-36.

101. Ingerslev J, Poulsen LH, Sorensen B. Potential role of the dynamic properties of whole blood coagulation in assessment of dosage requirements in haemophilia. Haemophilia 2003; 9: 348-52.

102. Sorensen B, Johansen P, Christiansen K, et al. Whole blood coagulation thrombelastographic profiles employing minimal tissue factor activation. J Thromb Haemost 2003; 1: 551-8.

103. Barrowcliffe TW, Cattaneo M, Podda GM, et al. New approaches for measuring coagulation. Haemophilia 2006; 12 (Suppl 3): 76-81.

104. Hemker HC, Al Dieri R. Age-dependency of thrombin generation. Thromb Haemost 2006; 95: 756-7. 105. Haidl H, Cimenti C, Leschnik B, et al. Age-dependency of thrombin generation measured by means of calibrated automated thrombography (CAT). Thromb Haemost 2006; 95: 772-5. 